\title{
HERMENETIK SEBAGAI DISKURSUS DALAM ARSITEKTUR
}

\author{
Ari Widyati Purwantiasning \\ Jurusan Arsitektur Universitas Muhammadiyah Jakarta \\ arwityas@yahoo.com
}

\begin{abstract}
ABSTRAK. Dalam sebuah penelitian, dikenal secara umum dua buah metode, yaitu metode kuantitatif dan metode kualitatif. Pada implementasinya, penelitian arsitektur lebih menitikberatkan dengan menggunakan metode kualitatif karena fokus pada obyek penelitiannya lebih kepada penafsiran dan opini akan obyek tersebut. Subyektifitas sangat dirasakan lebih tinggi daripada tingkat obyektifitas pada sebuah penelitian kualitatif, namun tidak menutup kemungkinan bahwa obyektifitas dalam sebuah penelitian kualitatif juga dapat dicapai dengan dasar teori yang cukup kuat sebagai pendukungnya.
\end{abstract}

Tulisan ini merupakan sebuah ulasan mengenai bagaimana ilmu hermenetik atau penafsiran dapat digunakan dalam sebuah penelitian arsitektur. Berbagai teori mengenai hermenetik dituangkan dalam tulisan ini sebagai sebuah diskursus. Tulisan ini juga merupakan bagian dari penelitian yang sedang dilakukan oleh penulis untuk mendukung metode penelitian yang akan dipilih dalam penelitian bidang arsitektur. Tulisan ini juga akan menjawab bagaimana hermenetik dapat digunakan dalam sebuah penelitian arsitektur. Dengan memaparkan ilmu hermenetik dalam tulisan ini, maka dapat diambil sebuah pelajaran tentang bagaimana langkah-langkah serta tahapan dalam menerapkan hermenetik pada penelitian arsitektur.

Kata Kunci: hermenetik, penelitian, arsitektur

ABSTRACT. Generally, there is two methods of research, quantitative and qualitative method. In the implementation of the architectural study, a qualitative approach has been used frequently and familiarly, because in architectural research usually focused on interpreting and giving an opinion of something, in this case, an object of the study. And for the result, the subjectivity of architectural research is high compared with the objectivity, but it is not possible to have an objective result in architectural research.

This article is a review of how the extent to which hermeneutic could be used in architectural research, and how the extent to which hermeneutic has a role in architectural discourse. Some theories of hermeneutic will be discussed in this paper as a discourse. This paper is also a part of research that still ongoing to support the method of the study that will be conducted by the researcher in architectural research. By describing this hermeneutic method in this paper, the researcher could underline the lesson about how are the steps and processes in the application of hermeneutic in architectural research.

Keywords: hermeneutics, research, architecture

\section{PENDAHULUAN}

Dalam sebuah penelitian arsitektur, metode kualitatif sangat sering dipilih oleh peneliti, karena paparannya dengan menggunakan deskripsi naratif dirasa lebih tepat dalam sebuah penelitian arsitektur. Sebuah karya arsitektur sebagai sebuah karya seni membutuhkan sebuah interpretasi atau persepsi dari seseorang yang mengamatinya. Dan pengamatan tersebut tentunya berbedabeda antara satu orang dengan orang yang lain, dikaitkan dengan preferensi dan pengalaman seseorang akan ilmu yang bersangkutan. Ketika sebuah karya arsitektur harus diulas dalam sebuah penelitian arsitektur yang dilakukan oleh seorang mahasiswa tentunya akan berbeda cara dan hasil mempersepsikan dan menginterpretasikannya dibandingkan dengan penelitian yang dilakukan oleh seorang ahli, seperti ahli sejarah, ahli perencanaan kota maupun seorang praktisi arsitektur. Oleh karenanya tingkat subyektifitas sebuah penelitian arsitektur terkadang diarasa sangat tinggi dibandingkan dengan tingkat obyektifitas sebuah penelitia arsitektur.

IImu untuk mempersepsikan dan menginterpretasikan sesuatu inilah yang disebut sebagai ilmu hermenetik. Di dalam sebuah penelitian arsitektur, hermenetik dianggap memiliki peranan sangat penting, karena dalam penelitian arsitektur, sebagian besar isinya adalah persepsi dan interpretasi dari si peneliti atau si penulis yang dituangkan dalam sebuah deskripsi naratif yang memiliki 
kronologi tertentu, terlebih untuk sebuah penelitian arsitektur yang menggunakan metode pendekatan sejarah dalam pelaksanaannya. Bagaimanakah penerapan hermenetik dalam penelitian arsitektur? Apakah hermenetik dapat digunakan dalam penelitian sejarah arsitektur? Apakah hermenetik juga dapat digunakan dalam mengulas suatu karya arsitektur? Tulisan ini akan menjawab pertanyaan-pertanyaan tersebut di atas melalui paparan beberapa teori dan ulasannya.

\section{HERMENETIK SEBAGAI SEBUAH DISKURSUS DALAM ARSITEKTUR}

Schmidt [1] dalam bukunya Understanding hermeneutika dapat dijelaskan sebagai sebuah metode untuk menafsirkan sesuatu. Sehingga dalam metode ini tidak ada "benar atau salah", yang ada adalah "benar atau keliru". Dalam menafsirkan sesuatu, setiap orang berbeda karena tergantung dari pengetahuan dasar setiap orang. Gadamer menyatakan bahwa hermeneutika merupakan teori "knowledge" secara filsafat, dimana semua pemahamannya harus melibatkan interpretasi dan aplikasi. Sebagai contoh adalah dalam memahami sebuah bacaan, di mana dalam sebuah bacaan kita tidak dapat memahaminya bagian demi bagian karena sebuah bacaan merupakan satu kesatuan atau keseluruhan makna yang disampaikan penulisnya. Dalam memahami isi bacaan inipun muncul interpretasi yang berbeda-beda antar pembaca, makna yang ingin disampaikan oleh penulis terkadang dipahami berbeda oleh pembaca.

Gadamer merujuk pada Schleiermacher yang menyatakan bahwa hermeneutika dalam pemahaman memerlukan bahasa tertulis maupun lisan. Sehingga dapat digarisbawahi bahwa dalam melakukan pemahaman dengan pendekatan hermeneutika dapat dilakukan dengan dua cara yaitu pendekatan gramatikal dan pendekatan psikologis.

Sementara itu Zygmunt Baumann [2] dalam bukunya Hermeneutics and Social Science: Approach to Understanding, menjelaskan bahwa hermeneutika termasuk dalam disiplin ilmu filologi (ilmu yang mempelajari sumbersumber bahasa dalam sejarah). Pendekatan hermeneutika digunakan dalam ilmu sosial sebagai metoda untuk melacak tujuan dari sebuah pemikiran, sehingga pemahaman diarahkan pada sebuah wacana dalam memahami sebuah keilmuan.

Dalam arsitektur, pendekatan hermeneutika dipaparkan oleh Alberto Gomez [3] dalam tulisannya berjudul Hermeneutic as Discourse in Design. Arsitektur memiliki pemahaman yang beragam dari berbagai sudut pandang, Hal ini menjadikan arsitektur sebagai wacana tersendiri bagi seorang arsitek dalam aktifitas proses perencanaan dan perancangan. Hermeneutika diperlukan oleh seorang arsitek dalam pemahaman konteks rancangannya. Apakah seorang arsitek akan melakukan pendekatan hermeneutika dahulu terhadap keinginan dan kebutuhan klien yang disesuaikan dengan kondisi lokasi/ lahan yang akan dibangun atau arsitek akan langsung melakukan kegiatan perancangan berdasarkan standar-standar keilmuan yang terdapat di dalam buku panduan atau yang didapatkan secara akademis.

Secara umum dalam ilmu arsitektur terdapat dua aspek penting yang harus diperhatikan oleh seorang arsitek, yaitu wacana sains dan wacana kesesuaian. Gomez menyatakan bahwa dalam sebuah disain tidak hanya estetika dan teknologi saja yang harus diperhatikan, namun juga harus didasari oleh kesesuaian dari kebutuhan si pemakai. Gomez juga menggarisbawahi adanya dua pendapat penting tentang wacana teori arsitektur. Pendapat pertama datang dari Claude Perrault yang mengkaitkan aspek biologi dan fisika dalam ranah arsitektur, dimana dapat dipahami di sini bahwa seorang arsitek harus merancang sesuai dengan proporsi bangunan dengan lahannya. Sementara pendapat kedua yaitu Peter Einseman yang menegaskan bahwa nilai dari teori arsitektur tergantung dari kemampuan teori tersebut diterapkan sehingga tidak terkait dengan sejarah. Sehingga dapat ditekankan di sini, bahwa tujuan hermeneutika menurut Gomez adalah pencapaian sebuah pemahaman arsitektur dalam mencari kebenaran. Seorang arsitek yang menggunakan pendekatan hermeneutika dalam proses desain, maka hasil sosok bangunan yang muncul adalah sesuai dengan interpretasi si arsitek terhadap keinginan dan kebutuhan kliennya yang disesuaikan dengan aspek budaya, sejarah, perilaku dan segala hal yang berkaitan dengan ilmu arsitektur. 


\section{HERMENETIK SEBAGAI SEBUAH BAGIAN DARI FENOMENOLOGI-ULASAN TEORI HUSSERL DAN HEIDEGGER}

\begin{abstract}
Husserl [4] mengemukakan bahwa fenomenologi dapat disebut sebagai pengetahuan esensi murni, dimana dalam prosesnya terdapat proses pemisahan dari yang dianggap pengalaman penting. Fenomenologi merupakan proses mencari ideide esensial dari pengalaman seseorang yang tidak dapat ditunjukkan dalam bentuk yang biasa atau umum. Husserl menyebutkan dua istilah "eidetic" dan "epoche" sebagai sebuah proses pemilahan fakta-fakta yang diserap dalam pikiran manusia. "Eidetic" yang berasal dari kata "eidos" yang berarti "form" atau bentuk, merupakan suatu proses mengidentifikasi komponen-komponen penting yang terjadi karena pengalaman individu dan memilah-milahnya.
\end{abstract}

Pemahaman yang ditangkap di sini adalah "eidetic" merupakan bentuk yang ditangkap dalam pikiran setiap individu. Husserl menyebutkan bahwa intuisi fenomenologi dari esensi memerlukan pergerakan dari pengalaman individu "here and now" menuju ke kontemplasi esensi itu sendiri. Sementara "epoche" yang berasal dari bahasa Yunani berarti menunda keputusan atau mengosongkan diri dari keyakinan tertentu. Epoche melibatkan dua istilah "bracketing" atau mengurung sesuatu dan "suspending" atau menunda sesuatu. Yang dimaksud di sini adalah mereduksi segala sesuatu yang diperoleh dari fakta-fakta dan fenomena yang nampak tanpa ada keputusan salah dan benar dahulu.

Fenomena yang tampil dalam kesadaran adalah benar-benar alami tanpa dicampuri oleh persepsi pengamat. Husserl memandang bahwa manusia pada dasarnya memiliki kecenderungan untuk bersikap natural dalam memahami dunia. Husserl menekankan bahwa fenomenologi digunakannya untuk memperoleh pengetahuan yang hakikat. Oleh karenanya dengan metode reduksi atau "epoche" tersebut, Husserl mengajak kita untuk menetralisasikan segala fakta-fakta dan fenomena yang ditangkap oleh pikiran kita sehingga tidak ada keterpihakan dalam menilai sesuatu. Metode reduksi ini bukan sebagai bentuk kesangsian akan fakta-fakta dan fenomena yang nampak. Sebagai contoh untuk mengetahui hakekat manusia, kita tidak perlu membandingkannya dengan makhluk lainnya seperti hewan dan tumbuhan, melainkan kita harus melihat dan memahami manusia sebagaimana yang nampak dalam kesadaran kita.

Dari pemahaman yang diperoleh, dapat diintisarikan bahwa Husserl mengklasifikasikan metode reduksi menjadi tiga jenis yaitu:

\section{Reduksi Fenomenologi}

Husserl menyebutnya dengan istilah "epoche" yaitu penangguhan akan suatu keputusan, dalam hal ini adalah menangguhkan segala pengandaian kita terhadap dunia. Husserl juga menyebutnya dengan proses mengurung atau "bracketing".

\section{Reduksi Eidetic}

Dipahami sebagai sebuah proses pemilahan sampai pada esensi tertentu dari sesuatu (eidos)

\section{Reduksi Transendental}

Husserl menggarisbawahi bahwa fenomenologi adalah suatu proses menangkap fenomena tidak lagi dari penglihatan alami manusia namun dari kesadaran pengalaman-pengalaman "noematic" (dari bahasa Yunani yang dijelaskan Husserl sebagai isi pikiran manusia, atau persepsi). Dengan reduksi transedental kesadaran mampu memahami sesuatu sebagai fenomena (obyek sebagai suatu fenomena).

Pada pembahasan selanjutnya, Husserl [5] menyatakan bahwa dasar pengalaman individu dalam mempersepsikan sebuah obyek adalah suatu proses yang dia sebut sebagai "passive genesis". Ketika proses tersebut melibatkan ego secara eksplisit, Husserl menyebutnya sebagai "active genesis". Bagaimana hal ini dipahaminya, harus menggunakan refleksi fenomenologi. Husserl juga mengatakan bahwa "passive genesis" harus dibedakan dengan konsep lain yang dikemukakannya yaitu "passive synthesis". Konsep "passive synthesis" merujuk pada cara kita ketika memperoleh pengalaman tentang sesuatu yang sudah terstruktur, dimana hal ini memperlihatkan bahwa pengalaman kita adalah pasif dan terstruktur.

Ketika Husserl [6] membahas fenomenologi sebagai sebuah kognisi dalam menangkap suatu fakta-fakta dan fenomena yang ada di dunia dan kemudian dituangkan kembali dalam persepsi yang berbeda-beda setiap individu, maka Heidegger mencoba untuk mengkritisi dan membantah konsep "eidetic" yang disampaikan Husserl. Bagi Heidegger, 
fenomenologi adalah sesuatu metode yang membawa pada cara baru dalam melihat sesuatu bukan sebagai suatu bentuk proposisi filsafat. Heidegger yang mengangkat konsep eksistensi atau kehadiran manusia - "human existence" dalam bukunya Being and Time berusaha menolak dan menjatuhkan konsep Husserl. Heidegger tidak lagi membahas masalah "kesadaran", "obyektifitas", "keteraturan", "noema", "noesis" dan "ego transendental". Heidegger juga tidak lagi merujuk pada "perilaku natural", "epoche" dan "reduksi". Sebaliknya Heidegger mencoba untuk mengarahkan fenomenologi sebagai model akses yang sesuai pada fenomena kehidupan manusia yang konkrit, kehidupan faktual.

Sementara itu, jika melihat kedua konsep filsafat Husserl dan Heidegger, keduanya memiliki perbedaan dalam mengkonsepkan fenomenologi. Jika Heidegger lebih kepada konsep "eksistensi" dengan bermetafisika, maka Husserl lebih kepada konsep "eidetic" dan "epoche" dengan mencari makna dengan proses membentuk suatu persepsi dari yang ditangkap pikiran tentang fakta-fakta dan fenomena yang ada.

Husserl memasukkan unsur kesadaran dan obyektifitas dalam konsep fenomenologinya. Sementara Heidegger berpegang pada "dasein" atau eksistensi sebagai dasar intensionalitasnya dalam filsafat.

Dari paparan di atas dapat diambil sebuah pemahaman bahwa fenomenologi merupakan suatu metode dan proses dalam melihat dan merangkum fenomena-fenomena yang ada sesuai hakekatnya. Fenomena dapat dipahami sebagai segala sesuatu yang tampil tertentu sesuai dengan kesadaran individu, baik sesuatu sebagai hasil persepsi seseorang maupun sesuatu yang faktual yang berupa ide atau kenyataan. Fenomenologi dapat juga dipahami sebagai suatu proses mendeskripsikan sesuatu sesuai dengan kesadaran individu seperti penampilan aslinya tanpa prasangka atau persepsi apapun. Seseorang yang menggunakan metode fenomenologi ini hendaknya dapat memahami fenomena sebagaimana adanya sesuai fakta tanpa ada dukungan sumber-sumber lain seperti teori, prasangka, praduga dan lainnya yang dapat merusak pemahaman aslinya. Husserl menyebutkan bahwa ada keterkaitan antara manusia dengan realitas yang harus dijalin dalam memahami sebuah fenomena. Sementara itu Heidegger menambahkan bahwa realitas itu membutuhkan kehadiran atau keberadaan manusia yang disebutnya sebagai eksistensi.

\section{PEMAHAMAN MELALUI PERSEPSI SEJARAH DAN KEHIDUPAN MANUSIA- ULASAN TEORI HEIDEGGER DAN WEBBER}

Heidegger [7] menyatakan bahwa pemahaman adalah "mode of being" daripada "mode of knowledge". Seperti halnya pada perspektif fenomenologi, Heidegger menekankan pada kata "being" yang merujuk pada istilah "eksistensi". Heidegger juga menyatakan bahwa secara konsekuensi, misteri dari sebuah pemahaman berdasar pada masalah "ontology" dari pada "epistemology". Sebuah aktifitas pemahaman merupakan aspek "being" dan juga "esensi" dari "eksistensi". Sehingga dapat digarisbawahi oleh Heidegger bahwa "eksistensi" adalah wacana itu sendiri. Pemahaman merupakan suatu proses dan menjadi masalah di dalam sebuah dunia. Heidegger mengangkat istilah "physis" pada pembahasan masalah eksistensi ini. Physis merujuk pada pernyataan Heidegger dapat dimaknai sebagai sesuati yang muncul "blossoming emergence", "opening up", "unfolding".

Physis adalah proses memunculkan sesuatu yang tadinya disembunyikan, dimana sesuatu yang tersembunyi itu akhirnya dibuat untuk muncul, melalui "poetic" fundamental, pengalaman eksistensi dari kehadiran daripada melalui penyamaan dari studi-studi alamiah. Physis dapat dikatakan juga sebagai "esensi" dari "being". Hadir dalam dunia yang merujuk pada frase "being in the world" merupakan hal yang layak terjadi bagi kehadiran manusia atau human existence. Dengan kehadiran manusia tersebut, maka perlu dicermati dalam pemahaman sesuatu dalam persepsi kehidupan manusia, Heidegger menekankan pada istilah antara "actuality" dan "potentiality" serta antara " $m e$ " dan "others". Heidegger juga membahas masalah komunikasi dengan yang lain atau "others" merupakan kondisi awal terjadinya kehadiran/ "eksistensi". Sehingga bagi segala sesuatu yang akan dimulai atau terjadi, sudah selayaknya harus ada eksistensi sebelumnya. Tidak akan terjadi sesuatu bila tidak ada kehadiran/ "eksistensi", hal ini yang ditekankan oleh Heidegger dalam memahami sesuatu dalam perspektif kehidupan manusia. Heidegger juga menekankan bahwa "ada" tidak dapat terlepas dari "waktu" seperti apa yang dikatakannya pada tulisannya "being and time". 
Lain halnya dengan Heidegger, Webber mencoba untuk melihat dari perspektif yang berbeda. Webber menjelaskan tentang pemahaman sesuatu dilihat dari persepsi sejarah. Webber membahas tentang "understanding" dan "interpretation" baik dalam "natural science" maupun "cultural science". Webber dalam tulisannya memaparkan bahwa faktanya, sosial lahir tidak dapat terlepas dari pemahamannya baik yang berkaitan dengan motivasi individu maupun yang berkaitan dengan tindakan sosial. Webber mengangkat istilah "vertehen" yang dapat dimaknai sebagai sebuah pemahaman subyektif dalam mendapatkan pemahaman yang valid mengenai sebuah arti subyektif dari tindakan sosial. Webber juga mengangkat istilah empati dan simpati dalam teorinya, karena dalam tindakan sosial yang berdasar subyektifitas dibutuhkan rasa empati atau simpati seseorang dalam menempatkan dirinya dalam kerangka berpikir orang lain yang melakukan tindakan.

Bagi Webber, manusia yang bersifat makhluk sosial adalah tokoh utama atau "actor" dalam kehidupan dunia, sehingga segala peristiwa di dunia seperti yang terjadi dan kita saksikan terwujud karena adanya tindakan sosial. Dalam kesehariannya, manusia melakukan sesuatu karena manusia ingin melakukannya, dan memutuskan untuk melakukannya untuk mencapai apa yang mereka kehendaki, dengan memilih suatu tindakan yang tepat tentunya. Sehingga secara tidak sadar, segala peristiwa yang terjadi karena akibat adanya interaksi antar individu yang terjadi karena adanya tindakan sosial seperti yang dikatakan oleh Webber. Webber juga menjelaskan bahwa "social action"/ tindakan sosial muncul karena adanya respon atau stimulus dari perilaku manusia yang menjalankan fungsinya sebagai makhluk sosial yang berperan sebagai anggota di masyarakat. Webber juga menjelaskan bahwa secara tidak langsung, tindakan ini bersifat subyektif karena dilakukan oleh seorang individu di dalam lingkungan masyarakat.

Selanjutnya, Webber [8] dalam paparannya menjelaskan tentang "social action" yang terbagi menjadi empat:

\section{1. wertrational/ value oriented rational/} value rational action

tindakan ini dikenal sebagai tindakan rasionalitas nilai, yaitu tindakan yang berkaitan dengan komitmen, sehingga ada nilai dan makna yang terkandung di dalamnya. Menurut Webber tindakan ini dilakukan dengan kesadaran penuh yang tidak terlepas dari suatu faktor seperti faktor agama, hukum atau bentuk lainnya.

2. zweckrational/ instrument oriented rational/ instrumentally rational action

Webber mengangkat istilah ini untuk menjelaskan sebuah tindakan yang didasarkan adanya kepentingan maupun tujuan tertentu dimana jalan pintas dianggap sesuatu yang pantas. Tindakan ini berkaitan dengan tindakan yang efisien untuk mencapai suatu tujuan.

\section{3. affectual action}

tindakan afektual didasari pada emosi atau sentimen yang dimiliki oleh seseorang dalam melakukan tindakan. Hal ini akan mempengaruhi respon orang lain saat tindakan tersebut dilakukan. Suasana atau peristiwa yang terjadi pada seseorang juga akan tergantung saat tindakan afektual ini terjadi, apakah suasananya positif atau negatif hal ini tergantung dari emosi yang ada pada individu tersebut saat tindakan tersebut terjadi.

\section{4. traditional action}

Tindakan tradisional dapat dimaknai sebagai tindakan yang berulang secara teratur yang dapat menjadi kebiasaan, walaupun belum tentu kebenaran dan keberadaannya. Tindakan ini dapat dikatakan juga sebagai tindakan yang merupakan warisan turun temurun dari generasi sebelumnya. Tindakan tradisional ini berkaitan erat dengan tradisi, kebiasaan, aturan adat atau custom.

Webber juga memunculkan istilah "understanding" sebagai sesuatu yang merupakan aksi yang berhubungan dengan "intellectual, analytical dan predictive explanation".

\section{PEMAHAMAN MELALUI PERSEPSI NALAR/ KESADARAN MURNI - ULASAN TEORI HUSSERL}

Edmud Husserl [9] merupakan filsuf yang dikenal sebagai filsuf paling radikal yang mengangkat ide rasionalistik sebagai pemahaman dalam menyelesaikan sebuah masalah pemaknaan. Pendekatan yang Husserl lakukan adalah melalui pendekatan hermenetik yang membahas tentang pencarian 
kebenaran melalui kesadaran murni/ "pure consciousness" seseorang.

Husserl memaknai fenomenologi sebagai suatu metode analisis deskriptif dengan mengutamakan esensi sebuah kesadaran murni yang disebutnya sebagai "pure consciousness". Pure atau murni di sini dijabarkan oleh Husserl sebagai fenomenologi transendental yaitu ilmu yang bersifat "eidetic" tentang "essential being". Lebih singkatnya dapat dipahami bahwa ilmu ini merupakan ilmu tentang esensi. Satu istilah yang digunakan Husserl dalam pemahaman melalui persepsi kesadaran murni ini adalah "phenomenology reduction", yang mensyaratkan adanya kesadaran individual sehingga membuang atau mereduksi semua informasi tentang sejarah maupun elemen sosial yang dapat membuatnya sebagai sesuatu yang absolut. Husserl menerima semua pikiran sebagai fenomena sejarah - yaitu sebagai peristiwaperistiwa yang tersimpan di dalam kepala setiap individu dalam sebuah momen khusus setiap waktunya.

Pemahaman menurut Husserl ditentukan dari peristiwa-peristiwa fisik yang terjadi di dunia, namun dia katakan bahwa pemahaman bukan lagi properti dari actor empiric atau produk negosiasi antara dua subyek otonomi yaitu si aktor itu sendiri dan si penafsir. Di dalam paparannya, Husserl mengangkat istilah "apodictic validity" yang dapat dimaknai sebagai suatu aktifitas untuk mendemonstrasikan sesuatu secara valid dan baik.

Sejak tidak adanya pemahaman "apodictic" semacam ini dapat didasari dalam fakta sejarah sebagai "being thought" dari sejarah individu, Dilthey menggarisbawahinya sebagai "knowledge of nature" dan "knowledge of spiritual" dimana kedua hal ini hilang dari teori Husserl. Bagi Husserl, pemahaman hanya dapat diselesaikan melalui teori umum tentang "knowledge" dan "truth". Husserl juga menjelaskan bahwa dalam setiap individu yang memiliki self evidence, self obviousness, self explication, akan memiliki kualitas esensi dari kehidupan di dunia yang diserap tiap individu secara naif.

Husserl menekankan bahwa dalam pemahaman yang didasari oleh kesadaran murni, semua ide yang berkaitan dengan eksistensi suatu obyek yang secara tidak sadar memberikan informasi pada kita tentang obyek tersebut, harus dihilangkan. Tepatnya, Husserl memfokuskan bahwa eksistensi sebuah obyek harus terpisah dan berdiri sendiri dari kehadirannya dalam alam sadar setiap individu. Proses inilah yang disebut Husserl sebagai "bracketing away" atau "epoche". Proses epoche inilah yang menurut Husserl dibutuhkan oleh seorang individu dengan mengurung semua hal yang berhubungan dengan asumsi. Epoche yang merupakan metode pembatasan ini membuat seorang individu tidak lagi tergantung validitasnya pada "spatio-temporal world". Seorang individu akan memahami sesuatu tidak dengan berdasar eksistensinya namun karena esensi suatu obyek tersebut.

Ada kesamaan antara teori "epoche"-nya Husserl dengan teori "retreat consciousness"nya Berkeley dan Fichte, yang menyatakan bahwa kesadaran adalah satu-satunya pengetahuan dasar yang dapat diakses oleh setiap individu. Di sini "epoche" dimaksudkan untuk mengeliminasi segala sesuatu yang berkaitan dengan faktor sejarah, budaya, dan sosial yang dapat bertindak sebagai operator dalam pemahaman sesuatu. Sehingga dalam pemahaman tersebut, tidak lagi dalam kesadaran murni, untuk itu dibutuhkan proses "epoche", sehingga dihasilkan suatu pemahaman esensi bukanlah eksistensi. Proses "epoche" atau "bracketing away" ini tidak hanya mengeliminasi sesuatu yang berkaitan dengan faktor-faktor yang telah disebutkan sebelumnya, namun juga berkaitan dengan segala sesuatu yang tidak mempengaruhi empirik seseorang.

Untuk merangkum paparan Husserl, maka dapat digarisbawahi di sini bahwa dalam pandangan Husserl, semua "knowledge" berisi pemahaman, sejak sesuatu hadir untuk kesadaran (are given) hanya dalam kondisi (being known), mungkin hanya dapat ditangkap sebagai makna bukan sebagai obyek yang hadir di sana dimana di dalam obyek tersebut terkandung berbagai pola dari "true knowledge". Makna tersebut bukan pikiran dan bukan peristiwa psikologis.

Bila makna tidak dihadirkan dengan pikiran/ psikis/ spirit yang nyata, dan individual empirik, maka makna akan diberikan melalui "transcendental subjectivity" dan melalui "intentional effort" dari subyektifitas yang bukan merupakan subyektifitas siapapun. Subyektifitas dapat dipahami sebagai sesuatu yang di dalam maknanya menghasilkan makna melalui aktifitas yang bertujuan khusus. Untuk memaknai hubungan kompleks antara "transcendental" dan "individual subjectivity", dapat dianalogikan dengan bagaimana membayangkan visual Tuhan sebagai sumber 
yang bertujuan atas segala makna. Namun Husserl tidak menggunakan hal tersebut untuk menganalogikan istilah "transcendental" dan "individual subjectivity", tetapi sebagai struktur berpikir dimana "transcendental subjectivity" sebagai inti dari semua makna dan sebagai kemungkinan untuk meraihnya melalui purifikasi hasrat "life-world" dapat dijadikan makna terbaik.

\section{KESIMPULAN}

Dalam ilmu arsitektur yang menggabungkan antara ilmu teknologi dan seni, memiliki kecenderungan mengedepankan kemampuan berinterpretasi dan berpersepsi. Sebagai sebuah contoh sebuah karya arsitektur dapat diulas dengan menggunakan kemampuan interpretasi dan persepsi seseorang. Dalam hal ini hermenetik memegang peranan penting pada ilmu arsitektur. Subyektifitas dianggap lebih tinggi daripada obyektifitas ketika menggunakan hermentik dalam wacana arsitektur, namun tidak menutup kemungkingan obyektifitas dapat dicapai dalam proses interpretasi tersebut, ketika menggunakan teori-teori yang disampaikan oleh para pakar filsuf. Subyektifitas dapat dihindari ketika dalam proses interpretasi tersebut, seseorang tidak dipengaruhi oleh pemikiran-pemikiran lain yang ada di kepalanya. Alur berpikir seseorang dalam melakukan proses hermenetik tersebut harus mengikuti teori yang diungkapkan oleh Husserl maupun Heidegger. Pada implementasinya, wacana hermenetik ini sangat penting dalam dunia arsitektur, sehingga wacana ini tidak dapat dipisahkan dalam duni arsitektur.

\section{REFERENSI}

[1] Schmidt, L. K. (2006). Understanding Hermeneutics. Acumen. hal. 1-28

[2] Baumann, Z. (1978). Hermeneutics and Social Science: Approach to Understanding. London: Hutchinson. Ch. 1

[3] Alberto Pérez-Gómez. (1999). 'Hermeneutics as Discourse in Design'. Design Issues. Volume 15 Number 2 Summer 1999. MIT

[4] Moran, D. (2000). Introduction to Phenomenology. hal. 132-134

[5] Moran, D. (2000). Introduction to Phenomenology. hal. 168-181

[6] Moran, D. (2000). Introduction to Phenomenology. hal. 226-238

[7] Baumann, Z. (1978). Hermeneutics and Social Science: Approach to Understanding. London: Hutchinson. Husserl: hal. 111-130
[8] Baumann, Z.. (1978). Hermeneutics and Social Science: Approach to Understanding. London: Hutchinson. Weber: hal. 69-88

[9] Baumann, Z. (1978). Hermeneutics and Social Science: Approach to Understanding. London: Hutchinson. Heidegger. 148-171 
